\title{
Kidney Function and Size in Type 1 (Insulin-Dependent) Diabetic Patients Before and During Growth Hormone Administration for One Week
}

\author{
J.Sandahl Christiansen ${ }^{1}$, J. Gammelgaard ${ }^{2}$, M.Frandsen ${ }^{1}$, H. Ørskov ${ }^{4}$ and H.-H.Parving ${ }^{3,5}$ \\ ${ }^{1}$ Steno Memorial Hospital, Gentofte, ${ }^{2}$ Ultrasound Laboratory and \\ ${ }^{3}$ Medical Department F, Herlev Hospital, Herlev, ${ }^{4}$ Institute of Experimental Clinical Research, Aarhus and \\ ${ }^{5}$ Department of Clinical Physiology, Bispebjerg Hospital, Copenhagen, Denmark
}

\begin{abstract}
Summary Kidney function and size were studied in seven well-controlled male Type 1 (insulin-dependent) diabetic patients before and after administration of highly purified human growth hormone for one week. Glomerular filtration rate, renal plasma flow (steady state infusion technique with urinary collections using ${ }^{125} \mathrm{I}$-iothalamate and ${ }^{131} \mathrm{I}$-hippuran), kidney size (ultrasonic scanning) and urinary excretion rates of albumin and $\beta$-2-microglobulin were measured. Highly purified growth hormone was injected subcutaneously, 2 IU in the morning and 4 IU in the evening. The growth hormone dosage applied induced an elevation in plasma growth hormone concentration from the normal level seen in these very well controlled diabetics to levels within the range previously demonstrated in normally controlled Type 1 diabetic patients. During the week of growth hormone administration, glycaemic control was maintained unchanged by increasing the insulin dose by 79 $\pm 9 \%$ (mean \pm SEM). Glomerular filtration rate increased from $122 \pm 3$ to $131 \pm 3 \mathrm{ml} / \mathrm{min} \times 1.73 \mathrm{~m}^{2}(p$ $<0.05)$ and renal plasma flow increased from $535 \pm$ 10 to $569 \pm 22 \mathrm{ml} / \mathrm{min} \times 1.73 \mathrm{~m}^{2}(p<0.05)$. Kidney size changed from $128 \pm 5$ to $133 \pm 5 \mathrm{ml} / 1.73 \mathrm{~m}^{2}$ (NS). Urinary excretion rates of albumin and $\beta$-2-microglobulin were unchanged. The present findings suggest that the growth hormone elevation typically found in Type 1 diabetic patients with reasonable clinical control, contributes to the enhanced glomerular filtration rate and renal plasma flow present in that disease.
\end{abstract}

Key words: Type 1 diabetes, glomerular filtration rate, renal plasma flow, kidney size, growth hormone, albumin, $\beta$-2-microglobulin.
Kidney function in patients suffering from Type 1 (insulin-dependent) diabetes mellitus of recent onset is characterized by enhancement of the glomerular filtration rate (GFR) [1-4]. Strict metabolic control for one week in newly diagnosed Type 1 patients reduces GFR, while the enlarged kidney size remains unchanged [5]. Several factors have been suggested as contributing to this rapidly reversible fraction of the GFR elevation in Type 1 diabetes - e.g. hypoxia [2], hyperglycaemia [6,7], hyperglucagonaemia [8] and increased plasma growth hormone $(\mathrm{GH})$ concentration [3]. Two hours GH infusion to normal man has no effect on kidney function [9], while GH administration for several days increases GFR as well as renal plasma flow (RPF) [10,11]. Until now no such data have been available for diabetic patients.

The aim of the present study was to investigate the effect of one week GH administration on kidney function and size in well controlled Type 1 diabetic patients. Highly purified GH was injected SC twice daily in order to obtain an elevation in plasma GH within the range previously demonstrated in poorly controlled Type 1 diabetes.

\section{Patients and Methods}

\section{Patients}

Seven male Type 1 diabetic patients participated in the study after giving informed consent (Table 1). All were lean and ketosis-prone. The patients were selected from those showing the best glycaemic control when seen in the outpatient clinic. The mean post-prandial blood glucose value found in the morning (at the last four visits to the outpatient clinic within one year before the study) was $7.9 \pm$ $0.9 \mathrm{mmol} / \mathrm{I}(\mathrm{SEM})$ and the mean $24 \mathrm{~h}$ urinary glucose excretion on the same occasions was $7 \mathrm{~g} / 24 \mathrm{~h}$ (range: $0-40 \mathrm{~g} / 24 \mathrm{~h}$ ). Glycosylated haemoglobin $1 c\left(\mathrm{HbA}_{1 c}\right)(12)$ was $8.0 \%$ (range: 5.8\%-10.8\%) (range in normal subjects: $4.8 \%-6.4 \%$ ). Ketonuria was not present before 
Table 1. Clinical data in seven Type 1 diabetic patients

\begin{tabular}{|c|c|c|c|c|c|c|}
\hline \multirow{2}{*}{$\begin{array}{l}\text { Patient } \\
\text { No. }\end{array}$} & \multirow{2}{*}{$\begin{array}{l}\text { Age } \\
\text { (years) }\end{array}$} & \multirow{2}{*}{$\begin{array}{l}\text { Duration } \\
\text { of diabetes } \\
\text { (years) }\end{array}$} & \multirow{2}{*}{$\begin{array}{l}\text { Body } \\
\text { surface area } \\
\left(\mathrm{m}^{2}\right)\end{array}$} & \multirow{2}{*}{$\begin{array}{l}\text { Weight } \\
\text { (\% of ideal) } \\
(19)\end{array}$} & \multicolumn{2}{|c|}{ Insulin requirement (IU kg $\left.{ }^{-1} \mathrm{day}^{-1}\right)$} \\
\hline & & & & & $\begin{array}{l}\text { Before GH } \\
\text { administration }\end{array}$ & $\begin{array}{l}\text { During GH } \\
\text { administration }\end{array}$ \\
\hline 1 & 26 & 1 & 1.97 & 97 & 0.21 & 0.37 \\
\hline 2 & 35 & 11 & 1.86 & 92 & 0.26 & 0.53 \\
\hline 3 & 20 & 1 & 1.81 & 96 & 0.30 & 0.60 \\
\hline 4 & 20 & 1 & 1.91 & 81 & 0.30 & 0.45 \\
\hline 5 & 31 & 1 & 1.80 & 85 & 0.16 & 0.29 \\
\hline 6 & 26 & 3 & 1.88 & 96 & 0.20 & 0.40 \\
\hline 7 & 38 & 3 & 1.75 & 97 & 0.43 & 0.62 \\
\hline Mean $\pm \mathrm{SD}$ & $28 \pm 7$ & 3 & $1.85 \pm 0.07$ & $92 \pm 6$ & $0.27 \pm 0.09$ & $0.47 \pm 0.12$ \\
\hline
\end{tabular}

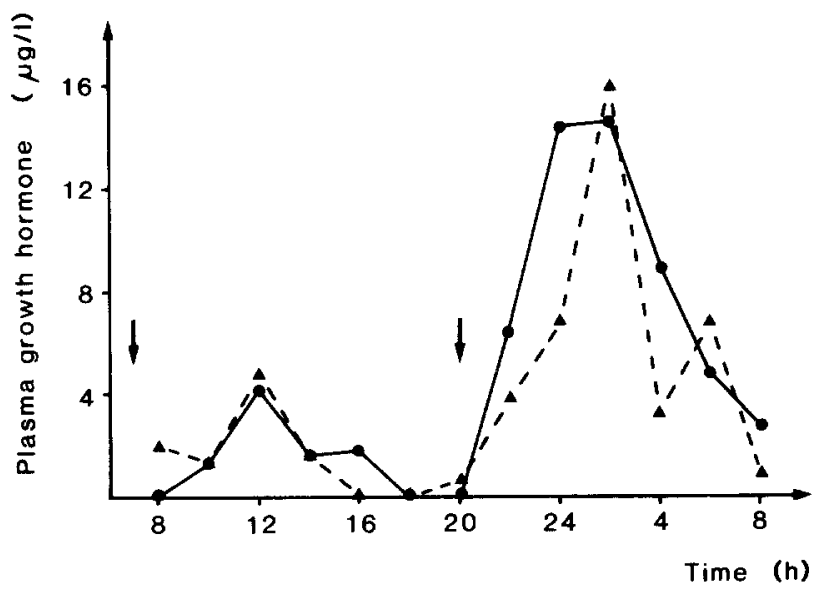

Fig. 1. Diurnal plasma growth hormone levels in two well-controlled Type 1 diabetic patients receiving human growth hormone SC. Arrows denote injection times: $2 \mathrm{IU}$ at $07.00 \mathrm{~h}$ and $4 \mathrm{IU}$ at $20.00 \mathrm{~h}$

or during the study. None had clinical signs of diabetic microangiopathy. The patients did not receive any medication apart from insulin.

\section{Methods}

GFR and RPF were measured using the steady-state constant infusion technique with urinary collections [13]. ${ }^{125}$ I-iothalamate and ${ }^{131}$ I-hippuran were used as markers of GFR and RPF respectively [13]. Measurements were carried out at $08.00 \mathrm{~h}$ following an overnight fast, the last injection of insulin being given the evening before.

The patients drank one litre of tap water at $07.00 \mathrm{~h}$ and were given 0.25 litres $/ 20$ min during the clearance experiments. Measurements were carried out in the supine position, the patients standing only to void. Following a 60 min equilibration period, six consecutive clearance periods, each of $20 \mathrm{~min}$, were evaluated. The GFR and RPF values are given as mean \pm SEM of all clearance periods and are corrected to $1.73 \mathrm{~m}^{2}$ body surface area.

Thyroid uptake of radioactive iodide was blocked with potassium iodide $100 \mathrm{mg}$ /day for 2 days before the study.

Kidney volume was measured by ultrasonic scanning [4, 14]. Measurements were performed at $15.30 \mathrm{~h}$ on the day before the determination of kidney function. The values given are the mean of double determinations corrected to $1.73 \mathrm{~m}^{2}$ body surface. The mean coefficient of variation on double determination in the present study was $4.1 \%$.

Urinary excretion of albumin and $\beta$-2-microglobulin were determined by radioimmunoassays $[15,16]$ and the values are given as mean \pm SEM of all six clearance periods. Plasma GH concentration [17] was measured during the first clearance period (at $09.00 \mathrm{~h}$ ). Blood glucose, heart rate $(60 \mathrm{~s})$ and auscultatory blood pressure were recorded in the middle of the first and last clearance periods.

\section{Protocol}

Measurements of kidney function and size were repeated after one week. GH administration was started in the evening on the day when the first determination of kidney function took place. The last injection was given in the morning on the day of the second measurement of kidney function. Growth hormone (Nanormon, Nordisk) was injected SC - 2 IU at 07.00 and 4 IU at $20.00 \mathrm{~h} \mathrm{[18].} \mathrm{In} \mathrm{a}$ pilot study on two well controlled Type 1 diabetic patients, this dosage was found to result in plasma $\mathrm{GH}$ levels within the range seen in Type 1 diabetic patients under ordinary clinical control [20](Fig.1).

We succeeded in keeping the metabolic control nearly unchanged during the experimental period by means of a standard regimen: the total daily insulin dose was increased by $60 \%$ at the beginning of the $\mathrm{GH}$ administration as indicated by our $24 \mathrm{~h}$ pilot study in two patients. Further adjustments of the insulin dosage were performed by means of daily telephone calls to the patients and based upon home measurements of glycosuria (Clinitest) six times a day. Duplicate $24 \mathrm{~h}$ urine collections for measurement of urinary glucose excretion were carried out immediately before each clearance procedure.

\section{Statistics}

The Wilcoxon matched-pair test was used for statistical evaluation.

\section{Results}

One week of $\mathrm{GH}$ administration induced a $7 \%$ increase in GFR $(122 \pm 3$ to $131 \pm 3 \mathrm{ml} / \mathrm{min} \times$ $\left.1.73 \mathrm{~m}^{2} ; p<0.05\right)$ and a $6 \%$ increase in $\operatorname{RPF}(535 \pm 10$ to $569 \pm 22 \mathrm{ml} / \mathrm{min} \times 1.73 \mathrm{~m}^{2} ; p<0.05$, Table 2). Filtration fraction remained unchanged. Kidney vol- 
Table 2. Glomerular filtration rate, renal plasma flow, kidney volume and glycaemic control in seven Type 1 diabetic patients before and after one week of growth hormone administration

\begin{tabular}{|c|c|c|c|c|c|c|c|c|}
\hline \multirow[t]{2}{*}{$\begin{array}{l}\text { Patient } \\
\text { No. }\end{array}$} & & & \multirow{2}{*}{$\begin{array}{l}\text { Glomerular } \\
\text { filtration rate } \\
(\mathrm{ml} / \mathrm{min} \\
\left./ 1.73 \mathrm{~m}^{2}\right)\end{array}$} & \multirow{2}{*}{$\begin{array}{l}\text { Renal plasma flow } \\
(\mathrm{ml} / \mathrm{min} \\
\left./ 1.73 \mathrm{~m}^{2}\right)\end{array}$} & \multirow[t]{2}{*}{$\begin{array}{l}\text { Kidney volume } \\
\left(\mathrm{ml} / 1.73 \mathrm{~m}^{2}\right)\end{array}$} & \multicolumn{2}{|c|}{$\begin{array}{l}\text { Blood glucose } \\
(\mathrm{mmol} / \mathrm{l})\end{array}$} & \multirow{2}{*}{$\begin{array}{l}\text { Urinary glucose } \\
\text { excretion } \\
\text { (g/24h) }\end{array}$} \\
\hline & & & & & & Period 1 & Period 6 & \\
\hline \multirow{2}{*}{1} & Before & GH & $121 \pm 2$ & $499 \pm 15$ & 124 & 8.7 & 6.6 & 3 \\
\hline & After & $\mathrm{GH}$ & $124 \pm 1$ & $486 \pm 9$ & 133 & 5.1 & 3.7 & 12 \\
\hline \multirow{2}{*}{2} & Before & $\mathrm{GH}$ & $120 \pm 1$ & $560 \pm 9$ & 151 & 5.0 & 5.0 & 0 \\
\hline & After & GH & $139 \pm 2$ & $623 \pm 13$ & 151 & 6.8 & 7.4 & 15 \\
\hline \multirow{2}{*}{3} & Before & $\mathrm{GH}$ & $131 \pm 2$ & $545 \pm 15$ & 117 & 6.6 & 8.5 & 2 \\
\hline & After & $\mathrm{GH}$ & $138 \pm 2$ & $546 \pm 9$ & 112 & 4.1 & 4.2 & 8 \\
\hline \multirow{2}{*}{4} & Before & $\mathrm{GH}$ & $128 \pm 3$ & $502 \pm 13$ & 128 & 4.8 & 4.1 & 0 \\
\hline & After & $\mathrm{GH}$ & $127 \pm 2$ & $518 \pm 10$ & 132 & 4.0 & 4.0 & 0 \\
\hline \multirow{2}{*}{5} & Before & $\mathrm{GH}$ & $107 \pm 1$ & $542 \pm 6$ & 112 & 4.1 & 5.0 & 0 \\
\hline & After & $\mathrm{GH}$ & $122 \pm 1$ & $641 \pm 9$ & 118 & 5.1 & 5.7 & 0 \\
\hline \multirow{2}{*}{6} & Before & GH & $127 \pm 3$ & $560 \pm 20$ & 133 & 6.1 & 5.6 & 9 \\
\hline & After & $\mathrm{GH}$ & $139 \pm 3$ & $613 \pm 19$ & 142 & 7.8 & 5.6 & 4 \\
\hline \multirow{2}{*}{7} & Before & $\mathrm{GH}$ & $119 \pm 1$ & $540 \pm 7$ & 131 & 6.3 & 7.1 & 58 \\
\hline & After & $\mathrm{GH}$ & $129 \pm 1$ & $558 \pm 8$ & 145 & 5.6 & 7.1 & 112 \\
\hline \multirow{3}{*}{ Mean } & Before & $\mathrm{GH}$ & $122 \pm 3$ & $535 \pm 10$ & $128 \pm 5$ & $5.9 \pm 0.6$ & $6.0 \pm 0.6$ & 10 \\
\hline & After & $\mathrm{GH}$ & $131 \pm 3$ & $569 \pm 22$ & $133 \pm 15$ & $5.5 \pm 0.5$ & $5.4 \pm 0.6$ & 22 \\
\hline & & & $2 p<0.05$ & $2 p<0.05$ & $0.05<2 p<0.1$ & & & \\
\hline
\end{tabular}

Results are expressed as mean $\pm \mathrm{SEM}$

${ }^{a}$ Mean of urinary glucose excretion for the 2 days before the first and the 2 days before the second evaluation of kidney function

ume increased from $128 \pm 5$ to $133 \pm 5 \mathrm{ml} / 1.73 \mathrm{~m}^{2}$ $(0.05<p<0.1$, Table 2$)$.

Plasma concentrations of $\mathrm{GH}$ increased from 2.0 \pm 0.8 to $8.3 \pm 0.5 \mu \mathrm{g} / 1$ (Table 3 ). Blood glucose levels during the 2 days of kidney function measurements were very similar (Table 2). Mean glycaemic control showed a minor deterioration in four patients, was unchanged in two and improved in one patient, as judged by comparison of glucose excretion during the 2 days before the first and second evaluation of kidney function (Table 2). The changes in GFR and RPF showed no relationship to the minor changes in glycaemic control (Table 2). A positive but statistically insignificant correlation was found between $\triangle$ GFR and $\triangle \mathrm{RPF}(r=0.58, p>0.1)$. No changes in urinary excretion rates of albumin or $\beta 2$-microglobulin were observed (Table 3$)$. Heart rate $(55 \pm 4$ versus $58 \pm 3$ beats $/ \mathrm{min})$ and blood pressure $(125 \pm 4 / 81 \pm 2$ versus $125 \pm 4 / 81 \pm 2 \mathrm{mmHg}$ ) showed no significant changes. Plasma protein concentration decreased from $70.8 \pm 0.5$ to $68.8 \pm 0.6 \mathrm{~g} / 1(p<0.05)$. Body weight was unchanged during the experimental period.

No patients reported any discomfort in connection with the administration of GH. All patients were again controlled on their ordinary insulin dose a few days after the termination of the study.
Table 3. Plasma growth hormone levels and urinary excretion rates of albumin and $\beta$ 2-microglobulin before and after one week of growth hormone administration in seven Type 1 diabetic patients

\begin{tabular}{|c|c|c|c|c|c|}
\hline $\begin{array}{l}\text { Patient } \\
\text { No. }\end{array}$ & & & $\begin{array}{l}\text { Plasma } \\
\text { growth } \\
\text { hormone } \\
(\mu \mathrm{g} / 1)\end{array}$ & $\begin{array}{l}\text { Urinary } \\
\text { albumin } \\
\text { excretion } \\
(\mu \mathrm{g} / \mathrm{min})\end{array}$ & $\begin{array}{l}\text { Urinary } \\
\beta 2 \text {-micro- } \\
\text { globulin } \\
\text { excretion } \\
\text { (ng/min) }\end{array}$ \\
\hline 1 & $\begin{array}{l}\text { Before } \\
\text { After }\end{array}$ & $\begin{array}{l}\mathrm{GH} \\
\mathrm{GH}\end{array}$ & $\begin{array}{r}2.1 \\
11.0\end{array}$ & $\begin{array}{l}4.1 \pm 0.2 \\
3.7 \pm 0.3\end{array}$ & $\begin{array}{l}37 \pm 2 \\
35 \pm 2\end{array}$ \\
\hline 2 & $\begin{array}{l}\text { Before } \\
\text { After }\end{array}$ & $\begin{array}{l}\mathrm{GH} \\
\mathrm{GH}\end{array}$ & $\begin{array}{l}3.8 \\
8.0\end{array}$ & $\begin{array}{l}2.7 \pm 0.1 \\
3.5 \pm 0.2\end{array}$ & $\begin{array}{l}19 \pm 1 \\
44 \pm 4\end{array}$ \\
\hline 3 & $\begin{array}{l}\text { Before } \\
\text { After }\end{array}$ & $\begin{array}{l}\text { GH } \\
\text { GH }\end{array}$ & $\begin{array}{l}5.6 \\
7.6\end{array}$ & $\begin{array}{l}3.4 \pm 0.1 \\
3.0 \pm 0.1\end{array}$ & $\begin{array}{l}42 \pm 2 \\
34 \pm 2\end{array}$ \\
\hline 4 & $\begin{array}{l}\text { Before } \\
\text { After }\end{array}$ & $\begin{array}{l}\text { GH } \\
\text { GH }\end{array}$ & $\begin{array}{l}0.2 \\
9.0\end{array}$ & $\begin{array}{l}4.5 \pm 0.2 \\
5.2 \pm 0.7\end{array}$ & $\begin{array}{l}153 \pm 18 \\
135 \pm 9\end{array}$ \\
\hline 5 & $\begin{array}{l}\text { Before } \\
\text { After }\end{array}$ & $\begin{array}{l}\text { GH } \\
\text { GH }\end{array}$ & $\begin{array}{l}0.0 \\
7.0\end{array}$ & $\begin{array}{l}3.0 \pm 0.1 \\
3.7 \pm 0.3\end{array}$ & $\begin{array}{l}73 \pm 10 \\
96 \pm 7\end{array}$ \\
\hline 6 & $\begin{array}{l}\text { Before } \\
\text { After }\end{array}$ & $\begin{array}{l}\mathrm{GH} \\
\mathrm{GH}\end{array}$ & $\begin{array}{l}0.0 \\
7.2\end{array}$ & $\begin{array}{l}4.9 \pm 0.8 \\
5.1 \pm 0.5\end{array}$ & $\begin{array}{l}206 \pm 5 \\
133 \pm 17\end{array}$ \\
\hline 7 & $\begin{array}{l}\text { Before } \\
\text { After }\end{array}$ & $\begin{array}{l}\mathrm{GH} \\
\mathrm{GH}\end{array}$ & $\begin{array}{l}2.0 \\
8.2\end{array}$ & $\begin{array}{l}3.1 \pm 0.5 \\
4.8 \pm 0.7\end{array}$ & $\begin{array}{r}70 \pm 7 \\
106 \pm 4\end{array}$ \\
\hline Mean & $\begin{array}{l}\text { Before } \\
\text { After }\end{array}$ & $\begin{array}{l}\mathrm{GH} \\
\mathrm{GH}\end{array}$ & $\begin{array}{l}2.0 \pm 0.8 \\
8.3 \pm 0.5 \\
p<0.01\end{array}$ & $\begin{array}{l}3.7 \pm 0.3 \\
4.1 \pm 0.3\end{array}$ & $\begin{array}{l}86 \pm 26 \\
83 \pm 17\end{array}$ \\
\hline
\end{tabular}

Results expressed as mean \pm SEM 


\section{Discussion}

The present study demonstrates an increase in GFR and RPF following one week of two daily subcutaneous GH injections to well controlled Type 1 diabetic patients. No significant changes in kidney volume were found, but numbers were small.

Data on kidney function following $\mathrm{GH}$ administration to diabetic patients have not been reported previously. In normal man, short-term infusion of GH has no effect on GFR and RPF [9], while GH injections for several days have been shown to increase GFR and RPF $[10,11]$ without concomitant changes in kidney volume [11]. Thus, the kidney response to an elevation in plasma $\mathrm{GH}$ seems to be similar in normal man and in well controlled Type 1 diabetic patients.

In order to obtain near normal $\mathrm{GH}$ concentrations before the administration of $\mathrm{GH}$, the diabetic patients in our study were carefully selected - most of them showing excellent glycaemic control. The control values for GFR and RPF $(122 \pm 3$ and $535 \pm 10 \mathrm{ml} / \mathrm{min}$ $\left.\times 1.73 \mathrm{~m}^{2}\right)$ in the present study are not statistically different from previous values we have obtained in nondiabetics (113 \pm 3 and $\left.523 \pm 21 \mathrm{ml} / \mathrm{min} \times 1.73 \mathrm{~m}^{2}\right)$ [4] and are significantly lower $(p<0.01)$ than results obtained from an unselected group of Type 1 diabetic patients with 'ordinary' clinical control (144 \pm 5 and $627 \pm 26 \mathrm{ml} / \mathrm{min} \times 1.73 \mathrm{~m}^{2}$ ) [4]. Likewise kidney volumes were found to be close to normal (128 \pm 5 versus $\left.112 \pm 5 \mathrm{ml} / 1.73 \mathrm{~m}^{2} ; p<0.05\right)$. Thus prolonged near-normal glycaemic control had apparently induced almost normal kidney function and size.

The twice daily subcutaneous GH injections applied in the present study induced an elevated diurnal plasma GH level within the range demonstrated in Type 1 diabetic patients under 'ordinary' clinical control [20] (Fig. 1).

The metabolic effect of $\mathrm{GH}$ administration to subjects deprived of insulin secretory capacity has recently been described [21]. Glycaemic control in the present study was maintained unchanged and equal to that before $\mathrm{GH}$ administration by a substantial increase in insulin dose $(79 \pm 9 \%)$. Blood glucose was similar during the clearance investigations before (mean $6.0 \pm 0.4 \mathrm{mmol} / \mathrm{l}$ ) and during $\mathrm{GH}$ administration (mean $5.5 \pm 0.4 \mathrm{mmol} / \mathrm{l}$ ). Glycosuria remained little changed in all patients except No. 7. It is well established that hyperglycaemia enhances GFR in Type 1 diabetes and in normal man [6,7]. Intravenous glucose infusion in Type 1 diabetic patients, resulting in an increase in blood glucose from 4.6 to $16.0 \mathrm{mmol} / 1$, raised GFR from 133 to $140 \mathrm{ml} / \mathrm{min} \times$ $1.73 \mathrm{~m}^{2}$ [7]. Mogensen, however, found no change in GFR in Type 1 diabetic patients [22] after a lesser elevation of blood glucose from 4.4 to $7.6 \mathrm{mmol} / 1$. Thus it seems fair to conclude that the enhancing effect of $\mathrm{GH}$ administration on kidney function in Type $1 \mathrm{di}-$ abetic patients is due to a direct action of $\mathrm{GH}$ and not dependent upon secondary changes in glycaemic control. This conclusion is strongly supported by our previous study in normal man [11], in whom GH administration identical to that in the present study induced an increase in GFR and RPF equal to that found in the present diabetic patients, but without any changes in glycaemic control.

Falkheden et al. [23] have suggested that the elevated GFR $(+23 \%)$ and RPF $(+20 \%)$ in acromegaly might be due to increased kidney size and enlarged extracellular fluid volume $(+33 \%)$. Even though plasma GH levels in acromegaly are more than tenfold higher than the levels obtained in the present investigation [24], it is possible that the enhanced GFR $(+7 \%)$ induced by 7 days $\mathrm{GH}$ administration might, to some extent, be due to extracellular fluid volume expansion. In the present study, no change in body weight was observed. Plasma protein concentration decreased by $3 \%$, indicating a plasma volume expansion in the same order of magnitude, assuming unchanged intravascular protein mass. However, the sampling of approximately $150 \mathrm{ml}$ of blood in the time between measurements might contribute to the slight decline in plasma protein concentration. In this context, it should also be mentioned that short-term experiments with plasma volume expansion due to saline infusion, resulting in even greater reductions in plasma protein concentration ( $4 \%-5 \%$ ), did not reveal any changes in GFR [7]. Thus, considering that GFR in the present study increased by more than $7 \%$, the slight extracellular fluid volume expansion would not seem to be the main mechanism involved in the enhancement of GFR.

Growth hormone can enhance GFR only by altering one or more of the well defined determinants of glomerular ultrafiltration [25]. These include RPF, transglomerular pressure and the glomerular permeability-surface area product. The present finding of a nearly parallel increase in GFR and RPF, with unchanged filtration fraction suggests that the rise in RPF is involved in the GFR enhancement induced by one week of $\mathrm{GH}$ administration.

No significant change in kidney volume was observed in the present study, although a tendency towards an increase was found (Table 2). The ultrasound technique applied has been shown to be accurate and precise [14]. The reproducibility of the technique should be sufficient (the coefficient of variation on double determinations in the present study was 4.1\%) to demonstrate an increase in kidney volume of the same magnitude as the present increase in GFR. 
No changes in the urinary excretion rates of albumin and $\beta 2$-microglobulin were found (Table 3 ). This is in accordance with the results obtained in normal subjects [11] and indicates that GH has no effect on the filtering properties of the glomerular capillary membrane or on tubular protein reabsorption.

The present results suggest that the GH elevation in Type 1 diabetes contributes to the enhancement of GFR and RPF typically found in these patients. The elevated GFR in Type 1 diabetic patients with 'ordinary' clinical control seems to be due to alterations in all the main determinants [4]. The elevated plasma GH may be implicated in at least two of them: an increase in RPF as well as an increase in filtration surface area. It has previously been suggested that the early hypertrophy and hyperfunction in Type 1 diabetes may in some way be related to the later development of diabetic nephropathy [26] and it has also been suggested that the elevated plasma $\mathrm{GH}$ is one of the factors leading to diabetic microangiopathy $[27,28]$.

Acknowledgements. The skilful technical assistance of U. M. Smidt, H. Kjeldsen, I. Bisgaard and K. Rasmussen, and the secretarial assistance of A. Jerichow are gratefully acknowledged. The study was supported by grants from the Danish Medical Research Council, Landsforeningen for Sukkersyge and Weiman's Legacy. Growth hormone (Nanormon) was kindly provided by Nordisk, Gentofte, Denmark.

\section{References}

1. Stalder G, Schmid R, Wolff MV (1960) Funktionelle Mikroangiopathie der Nieren beim behandelten Diabetes Mellitus im Kindesalter. Dtsch Med Wschr 85:346-350

2. Ditzel J, Junker K (1972) Abnormal glomerular filtration rate, renal plasma flow and renal protein excretion in recent and short-term diabetics Br Med J 2: 13-19

3. Mogensen CE (1972) Kidney function and glomerular permeability to macromolecules in juvenile diabetes. Dan Med.Bull 19: (suppl 3): 1-40

4. Christiansen JS, Gammelgaard J, Frandsen M, Parving H-H (1981) Increased kidney size, glomerular filtration rate and renal plasma flow in short-term insulin-dependent diabetics. Diabetologia $20: 451-456$

5. Christiansen JS, Gammelgaard J, Tronier B, Svendsen PA, Parving H-H (1982) Kidney function and size in diabetics, before and during initial insulin treatment. Kidney Int (in press)

6. Brøchner-Mortensen J (1973) The glomerular filtration rate during moderate hyperglycaemia in normal man. Acta Med Scand 194: 31-37

7. Christiansen JS, Frandsen M, Parving H-H (1981) Effect of intravenous glucose infusion on renal function in normal man and in insulin-dependent diabetics. Diabetologia 21:368-373

8. Parving $\mathrm{H}-\mathrm{H}$, Christiansen JS, Noer I, Tronier B, Mogensen CE (1980) The effect of glucagon infusion on kidney function in short-term insulin-dependent juvenile diabetics. Diabetologia $19: 350-354$

9. Parving H-H, Noer I, Mogensen CE, Svendsen PA (1978) Kidney function in normal man during short-term growth hormone infusion. Acta Endocrinol 89: 796-800
10. Corvilain J, Abramow M (1962) Some effects of human growth hormone on renal hemodynamics and on tubular phosphate transport in man. J Clin Invest 41: 1230-1235

11. Christiansen JS, Gammelgaard J, Ørskov H, Andersen AR, Telmer S, Parving H-H (1981) Kidney function and size in normal subjects before and during growth hormone administration for one week. Eur J Clin Invest 11: 487-490

12. Svendsen PA, Christiansen JS, Søegaard U, Welinder BS, Nerup J (1980) Rapid changes in chromatographically determined haemoglobin $A_{1 c}$, induced by short-term changes in glucose concentration. Diabetologia 19: 130-136

13. Mogensen CE (1971) Glomerular filtration rate and renal plasma flow in short-term and long-term juvenile diabetes mellitus. Scand J Clin Lab Invest 28:91-100

14. Rasmussen SN, Haase L, Kjeldsen H, Hancke S (1978) Determination of renal volume by ultrasound scanning. J Clinical Ultrasound 6:160-164

15. Miles DW, Mogensen CE, Gundersen HJG (1970) Radioimunoasy for urinary albumin using a single antibody. Scand J Clin Invest 26:5-11

16. Evrin PE, Petersen PA, Wide L, Berggård J (1971) Radioimmunoassay of $\beta$-2-microglobulin in human biological fluids. Scand J Clin Lab Invest 28:439-444

17. Ørskov H, Thomsen HG, Yde H (1968) Wick chromatography for rapid and reliable immunoassay of insulin, glucagon and growth hormone. Nature 219: 193-195

18. Danske Lægemiddel Standarder (1981) Human somatotropin for injection. Nyt Nordisk Forlag, Copenhagen pp 197-204

19. Natvig H (1956) Nye høide-veksttabeller for norske kvinner og menn. (New tables for height and weight in Norwegian women and men). Landsforeningen for Kosthold og Helse, Oslo

20. Hansen AP (1972) Serum growth hormone patterns in juvenile diabetes. Dan Med Bull 19: (suppl 1): 1-31

21. Metcalfe $P$, Johnston DG, Nosadini $R$, Ørskov $H$, Alberti KGMM (1981) Metabolic effect of acute and prolonged growth hormone excess in normal and insulin-deficient man. Diabetologia 20: 123-128

22. Mogensen CE (1971) Glomerular filtration rate and renal plasma flow in normal and diabetic man during elevation of blood sugar levels. Scand J Clin Lab Invest 28: 177-182

23. Falkheden T, Sjögren B (1964) Extracellular fluid volume and renal function in pituitary insufficiency and acromegaly. Acta Endocrinol 46: 80-88

24. Hansen KF, Rasmussen $P$ (1974) Urinary growth hormone in acromegaly. Acta Med Scand 195:381-384

25. Brenner BM, Humes HD (1977) Mechanisms of glomerular ultrafiltration. N Eng J Med 297: 148-154

26. Brenner BM, Hostetter TH, Olson JL, Rennke HG, Venkatachalam MA (1981) The role of glomerular hyperfiltration in the initiation and progression of diabetic nephropathy. Acta Endocrinol 97: (suppl. 242): 7-10

27. Poulsen JE (1953) Recovery from retinopathy in a case of diabetes with Simmonds' disease. Diabetes 2 (suppl): 7-12

28. Lundbæk K, Jensen VA, Steen Olsen T, Ørskov H, Christensen NJ, Johansen K, Hansen Aa P, Østerby R (1970) Diabetes, diabetic angiopathy and growth hormone. Lancet $2: 131-132$

Received: 30 June 1981

and in revised form: 23 November 1981

Dr. J.Sandahl Christiansen

Steno Memorial Hospital

DK-2820 Gentofte, Denmark 